\title{
PSYCHE.
}

\section{ON THE RELATION BETWEEN SCIENTIFIC AND ECONOMIC ENTOMOLOGY.}

BY CHARLES W. WOODWORTH, FAYETTEVILLE, ARK.

\begin{abstract}
[Annual address of the retiring president of the Cambridge Entomological Club, 9 January, 1891.]
\end{abstract}
The subject of this address is not of the kind usually chosen for similar occasions but is of none the less interest and importance. It is one also that is in full harmony with the genius of this society which is the recognition of the preeminence of what is called the philosophy of science. Another reason makes it of especial immediate importance to us. Economic entomology is upon the verge of an era of great advancement. The establishment of the agricultural experiment stations have added to its ranks more young men of scientific training and ability perhaps than have ever engaged in this line of investigation. If economic entomology is but a phase of scientific entomology then we want to put forth especial efforts to assimilate this young blood in our ranks; if on the other hand they are different and distinct, the difference will become more and more apparent as economic entomology develops and we should define our position as on the side of pure science.

I believe that the pure sciences are distinct from the economic sciences; that this is the primary division of science. We seem to be prone in this utilitarian age to try to find excuse for the pursuit of pure science by holding up the possibility of applying our discoveries for economic ends. Let us recognize and not act as though we were ashamed of the fact that the sole aim of the student of pure science is the discovery of truth, catering to human wants being entirely out of his province.

It may be said that laying aside this matter of sentiment, the human wants are supplied through the discoveries of science and that this is simply the application of science for economic purposes, or, to put it a little stronger, that economics are but applied sciences. Such a statement comes from the conception that facts are or in some way become the peculiar property of a science. This is not the case however. Perhaps if we could see all the intimate relations sciences have to each other we should say that every fact belongs to every science; at any rate we could scarcely name a fact which when closely viewed has not more than one bearing. An example of the far reaching character of a fact is that of the origin of species through evolution. When Darwin es- 
tablished the truth of this fact it soon came to be recognized that this basal fact of evolution was a fundamental principal of almost every other science which had occupied the attention of man. For economic purposes it is the facts which are appropriated, and in the same way that the biologist appropriates the facts discovered by the chemist. Economic sciences no more become departments or applications of other sciences by using some of the same facts than biology becomes a department or application of chemistry.

It may be further contended that in the cases cited above we have to do with real sciences but that the so called economic sciences have no right to the title of science, that they are essentially different. This will lead us to a consideration of what a science is. We have just seen that it does not consist of a body of facts peculiar to itself, but on the other hand it is evident that facts are closely connected with it, that it depends indeed on a set of facts, and further that these facts have some definite relation to each other and are susceptible of a rational classification. This classification is not the science as it cannot express nearly all the relationships, but these relationships do constitute the science. Any one science does not comprehend all the bearings of any fact but only such as have a relation to that one subject. The science of entomology, for example, consists the of relationship of the facts to insects. The relation of the same facts to the subject of plant diseases belongs to another science. When the subject is economic, the production of honey, the feeding of stock, or the like, are there any grounds upon which we can refuse it the title of science?

The economic sciences are all infantile, many perhaps not yet even conceived of by man. They are the only true foundation to the useful arts. Agriculture is a science though hidden by a mass of misconception and empiricism. It must make its advances by the same methods that have made the pure sciences what they are. A clear conception of the object and structure of the science and experimentation with all the conditions under control are essential. Economic entomology as generally understood is chiefly a department of agriculture but includes much heterogeneous material. To be a scientifically rational term, it must, like some of the genera of the older naturalists, be restricted. I can in no better way show the difference between it and scientific entomology than to indicate the parts of economic entomology and show where they belong among the economic sciences.

Insects of economic importance may be grouped into six categories. First, those directly injurious to man, which properly forms a department of medicine. Second, those attacking the domestic animals, a part of veterinary medicine. Third, those injuring cultivated plants, which includes by far the major part of the injurious insects and to which the term economic entomology should be restricted; it is only a part and perhaps not a natural part of the 
science which deals with the diseases of cultivated plants. Fourth, those which destroy other property ; in this category are the insects attacking furs, woollen goods, etc., and the food stuffs, which belong to domestic economy and at the saine time to commerce; library insects belong to library economy and so on. Fifth, those directly beneficial to man, which includes the bee, the silk worm, etc., industries which form one of the primary divisions of agriculture. Sixth, those indirectly beneficial to man by destroying the injurious insects; these in- sects of course belong to the sciences that consider the insects which are their victims.

Finally, to recapitulate, scientific entomology is a department of biology, economic entomology of agriculture. They have all the difference between them that there is between a pure science and an economic science. Can we as a society include them both? I think we should not. On the other hand the economic entomologists are nearly all at the same time scientific entomologists. These we can and do welcome.

\title{
A LIST OF THE ORTHOPTERA OF ILLINOIS.-II.
}

\author{
BY JEROME MCNEILL, FAYETTEVILLE, ARK.
}

\section{LOCUSTIDAE.}

19. Scudderia curvicauda De Geer. This is an abundant species in Illinois in suitable localities. Its favorite haunt is the wild meadows and prairies covered with coarse grasses and weeds. It is the only one of the katydids that flies freely in the daytime. It is in fact crepuscular rather than nocturnal. It may be seen flying at any hour of the day, but its note is not generally heard until the middle of the afternoon. The note cannot be supposed to represent more than the first two syllables of the "Ka-ty-did" or "Ka-ty-did-n't" of its congeners. It is made but once and the rasping jerky sound has been very well represented by $\mathrm{Mr}$. Scudder as bzrrin. It has been found at Moline as early as the 2 Ist of July.

20. Scudderia fuscata Brunner. This species is more abundant than the last but it too must be looked for in the right place. It is even less domestic in its habits than curvicauda. The latter is sometimes found about houses and gardens in town but the former is almost never seen in town. It may be looked for in the shrubs and undershrubs of open woods and clearings and in weedy fields and meadows. Its note is indistinguishable from that of curvicauda but it is much less frequently heard. The earliest recorded date of its capture at Moline is August 4th.

21. Amblycorypha oblongifolia De 

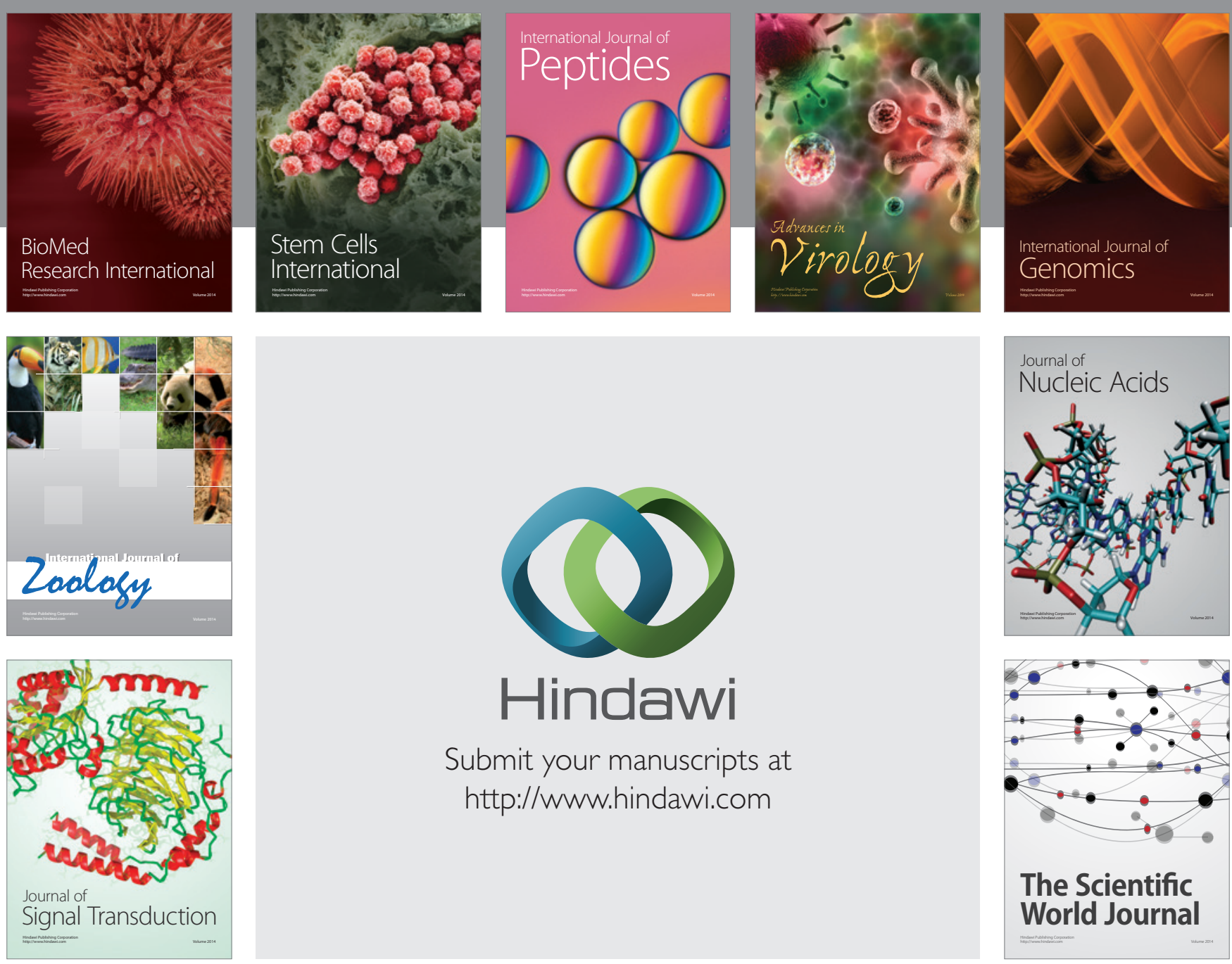

Submit your manuscripts at

http://www.hindawi.com
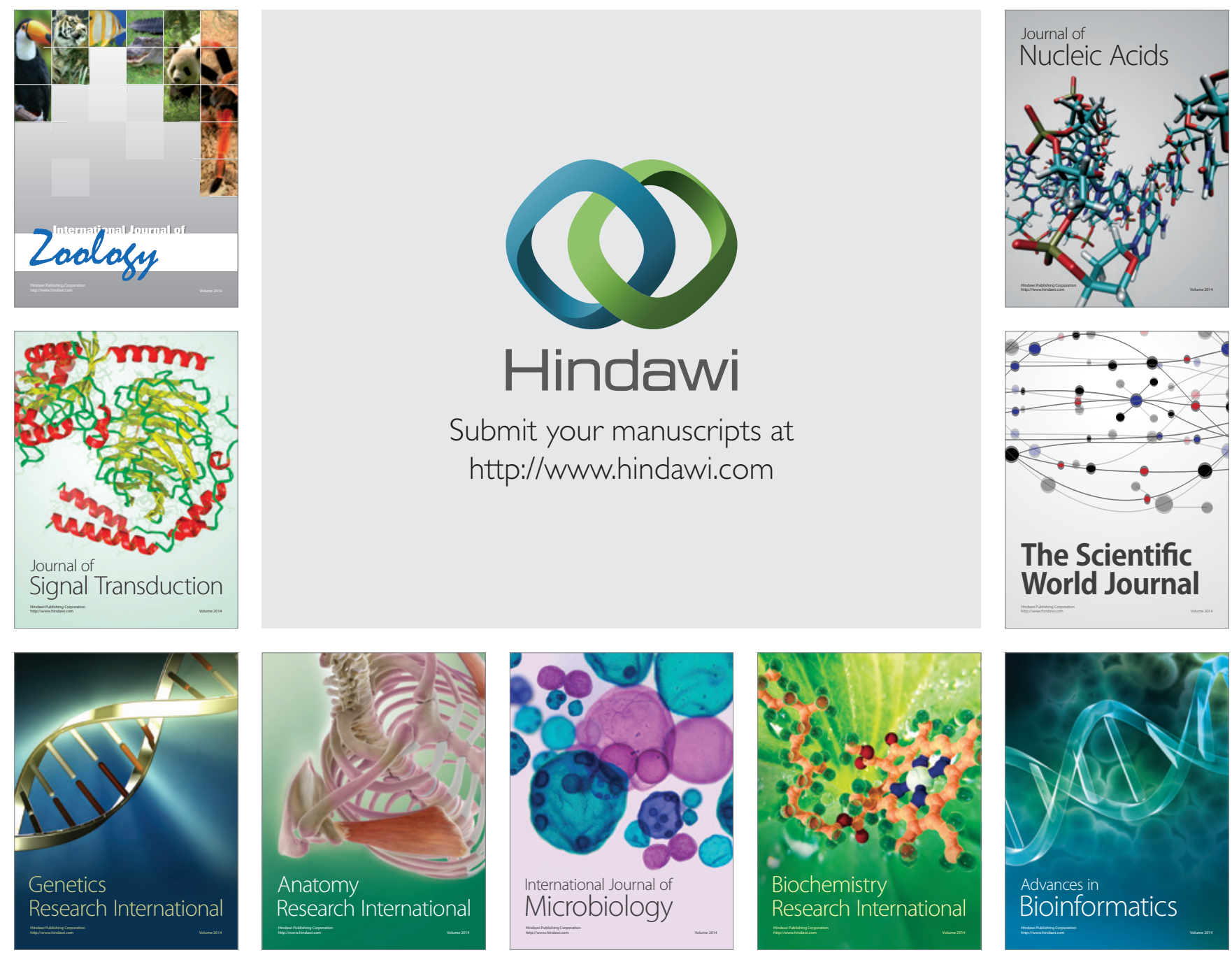

The Scientific World Journal
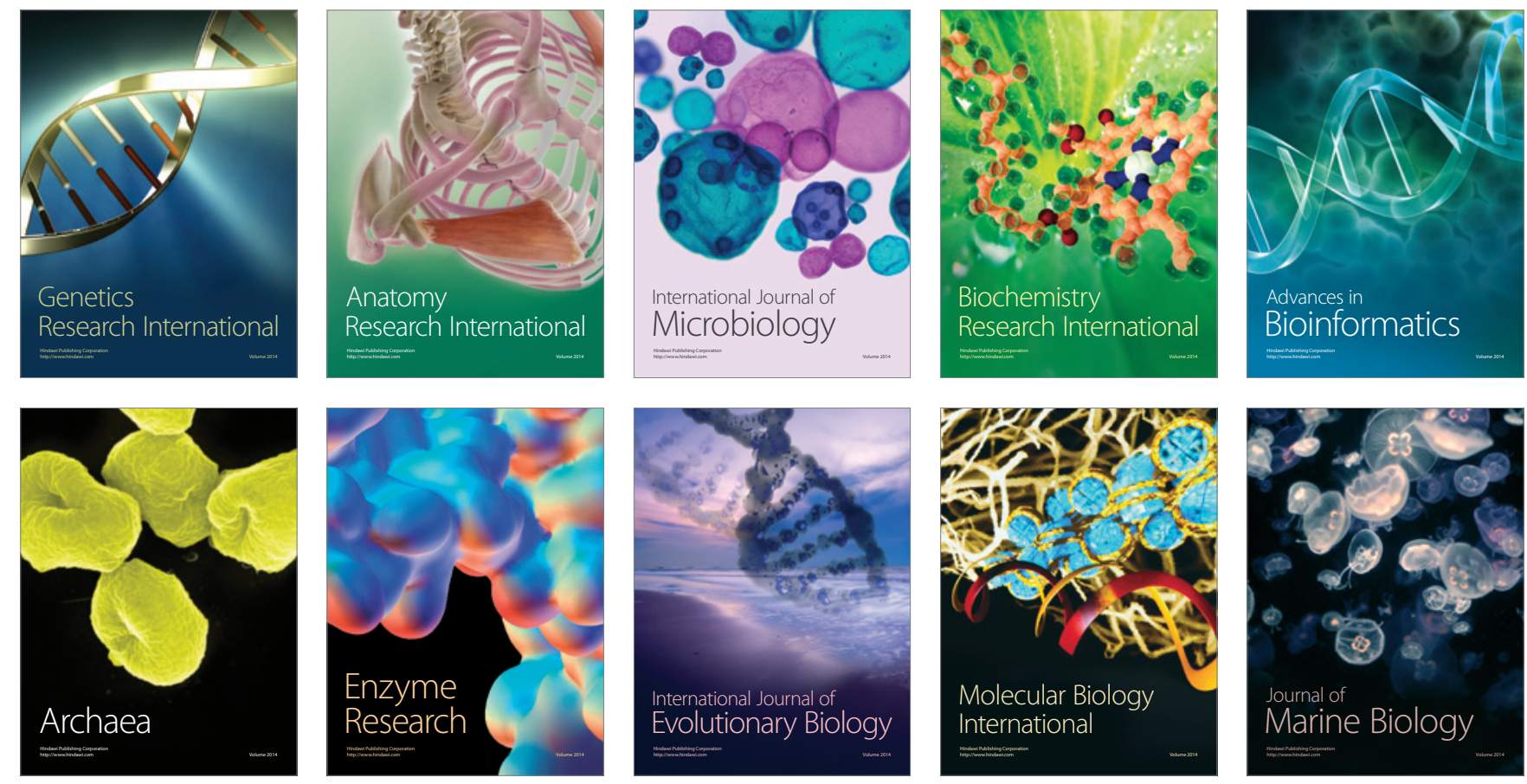